\title{
A new sediment dwelling and epizoic species of Olifantiella (Bacillariophyceae), with an account on the genus ultrastructure based on Focused Ion Beam nanocuts
}

\author{
Aydin Kaleli ${ }^{1 *}$, Marta Krzywda ${ }^{2}$, Andrzej Witkowski ${ }^{2}$, Catherine RiauX- \\ GobIN $^{3,4}$, Cüneyt Nadir SolaK ${ }^{1}$, Izabela ZGıOBICKA ${ }^{5}$, Tomasz PŁociŃski ${ }^{5}$, Justyna \\ GrzonkA $^{5}$, Krzysztof J. KurzydŁowski ${ }^{5}$, Ana CAR $^{6}$, Catherine Desrosiers ${ }^{7}$, \\ Yakup $\mathrm{KASKA}^{8}$ \& Kevin MCCARTNEY ${ }^{9}$
}

\author{
${ }^{1}$ Department of Biology, Faculty of Science \& Art, Dumlupınar University, 43000 Kütahya, Turkey; \\ *Corresponding author e-mail:aydinkaleli84@gmail.com \\ ${ }^{2}$ Palaeoceanology Unit, Faculty of Geosciences University of Szczecin, Mickiewicza 16A, PL-70-383 Poland \\ ${ }^{3} P S L$ Research University, CNRS-EPHE-UPVD, USR 3278 CRIOBE, F-66860 Perpignan, France \\ ${ }^{4}$ Laboratoire d'Excellence 'CORAIL', Université de Perpignan, F-66860 Perpignan, France \\ ${ }^{5}$ Faculty of Materials Science and Engineering, Warsaw University of Technology Woloska 141, PL-02-507 \\ Warsaw, Poland \\ ${ }^{6}$ Institute for Marine and Coastal Research, University of Dubrovnik, HR-20000 Dubrovnik, Croatia \\ ${ }^{7}$ Laboratory of Functional Ecology and Environment, Université Paul Sabatier, UMR ECOLAB bât 4R1, 31062 \\ Toulouse Cedex 9, France \\ ${ }^{8}$ Pamukkale University, Faculty of Science and Arts, Department of Biology, Denizli, Turkey \\ ${ }^{9}$ Department of Enviromental Science and Sustainability, University of Maine at Presque Isle, Presque Isle, \\ ME 04769, USA
}

\begin{abstract}
The marine diatom Olifantiella Riaux-Gobin et Compère predominantly occurs in tropical IndoPacific coral reef environments. The genus has about a dozen validly published taxa and is characterized by transapically elongate striae composed of a macroareola, broad perforated girdle, and tubular buciniportula process of trumpet-shape. The valve mantle of taxa related to the generitype, O. mascarenica, have a canalshaped structure around the valve at the face / mantle junction, while those to $O$. gorandiana have a simple mantle or strongly narrow canal and complex buciniportula composed of hollow processes. The geographic distribution of Olifantiella is expanded in this study to include species observed in loggerhead sea turtles scrapes from the Aegean Turkish coast and samples from the Turkish Black Sea and Adriatic Sea coasts. Olifantiella has also been identified in Martinique Island, Caribbean Sea. A transfer of Navicula infirmitata is proposed due to the areola and buciniportula structure, as Olifantiella infirmitata. Further, an application of the Focused Ion Beam (FIB) to a sequential cutting of frustules allows resolution of Olifantiella mascarenica valve ultrastructure.
\end{abstract}

Key words: diatoms, epizoic, Focused Ion Beam technique, marine coasts, new species, Olifantiella, sediment dwelling, ultrastructure

\section{INTRODUCTION}

Small-sized biraphid pennate diatoms of genus Olifantiella Riaux-Gobin et Compère have been described from coral reefs of Rodrigues Island, Indian Ocean, with $O$. mascarenica Riaux-Gobin et Compère (RIAUX-Gobin \& Compère 2009) selected as generitype. Olifantiella gorandiana Riaux-Gobin, $O$. paucistriata Riaux-Gobin, O. pilosella Riaux-Gobin, $O$. pseudobiremis Riaux-Gobin and O. rodriguensis Riaux-Gobin were described in RIAUX-GobIN \& ALHANDAL (2012) from Western Indian Ocean. In addition $O$. pilosella var. rhizophorae Riaux-Gobin and $O$. societatis Riaux-Gobin were described from tropical waters of Indian and Pacific Oceans by RIAUX-GobIN (2015). More recently, Olifantiella elisabethiana Van 
De Vijver was described from Antwerp, Belgium by VAN De ViJVer et al. (2016). Taxa belonging in Olifantiella are small and difficult to identify under light microscopy (LM) and only observations with scanning electron miscroscopy (SEM) can differentiate between particular taxa (LoBBAN et al. 2012; RiAuXGobin \& Al-Handal 2012; Riaux-Gobin 2015). Following characters have been listed as characterizing Olifantiella (RIAUX-GOBIN 2015, and emended definition in RiauX-Gobin \& AL-Handal 2012, p. 216):

- Transapically elongate striae composed of a single areola (the so-called macroareola)

- Presence of remarkable tubular process - buciniportula, raised or not

- Broad girdle composed of numerous perforated bands

- Marginal ridge, more or less deep, stepping over the striae

Based on the early identifications of Olifantiella, observed species were confined to tropical waters of the Indopacific (RIAUX-GoBIN 2015). However, recent findings in the Martinique Island littoral zone (DESROSIERS 2014) and description of $O$. elisabethiana from the North Sea coast (Antwerp Harbour in Belgium) expands the geographic distribution of Olifantiella to tropical and temperate Atlantic waters (Fig. 1).
The establishment of genus Olifantiella was preceded by Labellicula Van de Vijver et Lange-Bertalot (VAN De ViJVER et al. 2005). The latter was monotypic as $L$. subantarctica Van de Vijver et Lange-Bertalot until description of a second species, L. lecohuiana Majewska et Van de Vijver in MaJewska et al. (2017). Both genera possess a process with simple stigmata structure in Labellicula (VAN DE VIJVER et al. 2005) and rather complex, tubular design in Olifantiella (RIAUx-GoBIN \& Compère 2009; Riaux-Gobin 2015). Despite a strong similarity between the two genera, process structures of Labellicula and Olifantiella are easily distinguished in SEM micrographs. The buciniportula show some variation in established Olifantiella species. Three different types of buciniportula are observed: 1) Buciniportula showing raised tubular structure in $O$. mascarenica, 2) double tubular and raised structure in $O$. rodriguensis, and 3 ) double or multiple and flattened tubular structures in O. gorandiana.

If the process is not observed, the major difference is that Olifantiella has external central raphe endings always bent into the primary valve side, but towards the valve secondary side for Labellicula. This means that in Labellicula external proximal raphe endings tend to bend towards the valve face process opening, whereas proximal raphe endings externally bend outwards the process opening in Olifantiella (VAN DE

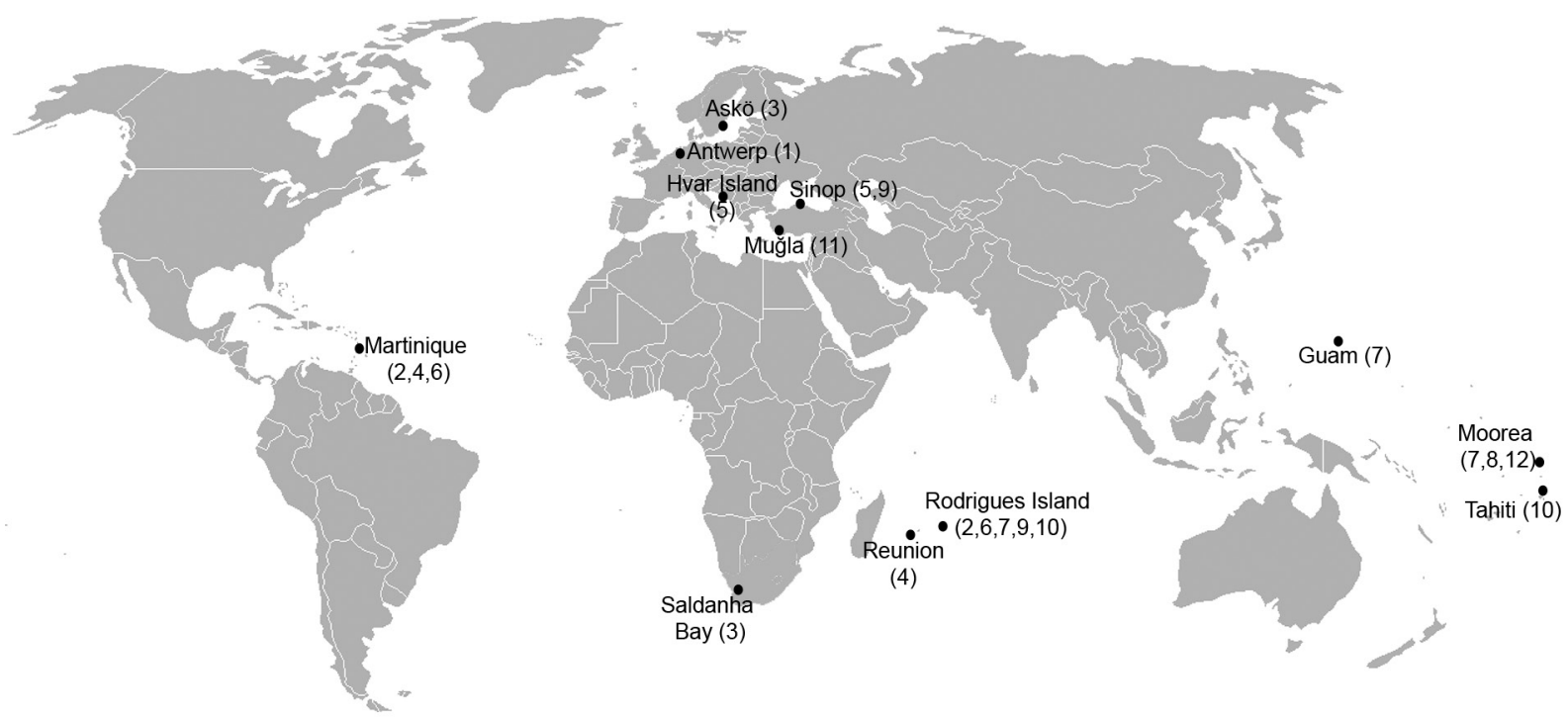

Fig. 1. Distribution of Olifantiella Riaux-Gobin et Compère: (1) Olifantiella elisabethiana Van de Vijver - Antwerp (VAN DE VIJVER et al. 2016); (2) Olifantiella gorandiana Riaux-Gobin - Rodrigues Island, Martinique Island (RIAuX-Gobin \& AL-Handal 2012; Desrosiers et al. 2014; RiauX-GobIN 2015); (3) Olifantiella infirmitata (Giffen) Witkowski et Snoeijs comb. nov. - Saldanha Bay, South Africa, Askö, Sweden (Giffen 1975; Snoeiss \& Kautsky 1989; Snoeiss \& Notter 1993); (4) Olifantiella mascarenica Riaux-Gobin et Compère - Reunion, Martinique Island (Riaux-Gobin \& Compère 2009; Desrosiers 2014; RiauX-Gobin 2015), Martinique Island; (5) Olifantiella cf. mascarenica Sinop, Stari Grad Bay, Hvar Island, Central Adriatic, Croatia - This study; (6) Olifantiella paucistriata Riaux-Gobin - Rodrigues Island (RiauX-Gobin \& AL-Handal 2012), Martinique Island (Desrosiers 2014); (7) Olifantiella pilosella Riaux-Gobin - Rodrigues Island, Moorea Island \& Guam (LobBan et al. 2012; RiauX-Gobin \& AL-Handal 2012; RiauX-Gobin 2015); (8) Olifantiella pilosella var. rhizophorae Riaux-Gobin - Moorea Island (Riaux-Gobin 2015); (9) Olifantiella pseudobiremis Riaux-Gobin - Rodrigues Island (RIAux-Gobin \& AL-Handal 2012; Riaux-Gobin 2015), also in Moorea Island (C.R. -G. Pers. obs.), Sinop - This study; (10) Olifantiella rodriguensis Riaux-Gobin - Rodrigues Island \& Tahiti Island (Riaux-Gobin \& AL-Handal 2012; Riaux-Gobin 2015); (11) Olifantiella seblae Kaleli, Krzywda, Witkowski et Solak sp. nov. - Dalyan, Muğla, Turkey - This study; (12) Olifantiella societatis Riaux-Gobin - Moorea Island (RIAUX-GoBIN 2015). 
ViJVER et al. 2005; RiAUX-Gobin \& COMPÈre 2009; RIAUX-GobIN 2015).

In this paper, Olifantiella seblae sp. nov. is described as an epizoic species on loggerhead sea turtles (Caretta caretta Linnaeus 1758) from Aegean Sea coasts of Turkey. Furthermore, transfer of Navicula infirmitata GIFFEN is proposed into Olifantiella infirmitata comb. nov., with ultrastructural observations detailing the buciniportula and macroareola. Occurrences of several Olifantiella taxa are reported from the Adriatic, Aegean and Black Seas. Also, we present for the first time nanocuts of Olifantiella mascarenica by means of Focused Ion Beam (FIB): The siliceous frustules have been cut at nanoscale and imaged.

\section{Material ANd Methods}

Loggerhead sea turtle scrapes originated from Dalyanİztuzu on the Aegean Sea coast $\left(36^{\circ} 42^{\prime} 02^{\prime \prime} \mathrm{N}, 28^{\circ} 41^{\prime} 31^{\prime \prime} \mathrm{E}\right)$ in southwest Turkey. Dalyan-İztuzu beach is an important Mediterranean nesting site (MARGARITOULIS et al. 2003) for loggerhead sea turtles. The sample location is a protected area with conservational studies made by DeKAmer (Sea Turtle Research, Rescue and Rehabilitation Center, CANBOLAT 2004; BaşKale \& KaSka 2005). During the nesting season (late April to early September), sea turtles that come to lay eggs are measured (BOLTEN 1999), tagged and nests are protected with cages by authorized staff at the rescue center. The protection center has responsibility for treatment and rehabilitation of injured turtles.

Epizoic diatom samples were collected from the nesting loggerhead sea turtles in Dalyan-İztuzu, Muğla during the nesting season between May - August, 2012-2016. Samples were brushed from sea turtle carapaces at night.

The holotype slide of Navicula infirmitata and unmounted material studied in this paper originated from Malcolm H. GIFFEn collection and have been provided by Colin Archibald (CSIR, Durban, South Africa). Currently, the collection is maintained by Dr. Jonathan TAYLOR at North-West University, Research Unit for Environmental Sciences, in Potchefstroom, South Africa under custody of the South African Institute for Aquatic Biodiversity (SAIAB), Grahamstown, South Africa (NIWR).

A diatom sample from the invasive alga Caulerpa taxifolia (M. VAHL) AGARDH No. SZCZ 14361, was collected on Hvar Island (Stari Grad Bay, Central Adriatic) on April 20,2009 . This area $\left(43^{\circ} 10^{\prime} 54^{\prime \prime} \mathrm{N}, 16^{\circ} 35^{\prime} 00^{\prime \prime} \mathrm{E}\right)$ has been affected by $C$. taxifolia at depths ranging from 5 to $8 \mathrm{~m}$. $C$. taxifolia was observed in Stari Grad Bay for the first time in 1994 on hard, sandy and muddy substrates without vegetation or within meadows of Posidonia oceanica (ŽULJEviĆ \& ANTOLIĆ 2002). The diatom samples were also collected from epipelic and epilithic habitats from Akliman Bay, Sinop, located in Southern Black Sea coast $\left(42^{\circ} 02^{\prime} 36^{\prime \prime N}\right.$, 35 02'46"E) in December 2012.

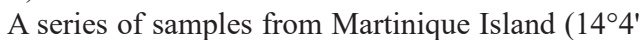
$\mathrm{N}, 61^{\circ} \mathrm{W}$ ), surrounded by the Atlantic Ocean and Caribbean Sea, have been analysed by means of LM and SEM. Samples were collected from the littoral zone, from Plexiglas ${ }^{\circledR}$ plates submerged at $3 \mathrm{~m}$ depth for five weeks. Olifantiella was found on sites located on the Caribbean sea side, with often high concentration of suspended matter and turbidity (Desrosiers 2014). Part of the research on Martinique Island diatoms including SEM has been performed at Warsaw University of Technology in fall 2012 (cf. DesRosiers 2014). During this time also FIB cutting of Olifantiella mascarenica has been made, however, the results have not been published thus far.

Samples were washed with $10 \% \mathrm{HCl}$, boiled in 30 $\% \mathrm{H}_{2} \mathrm{O}_{2}$ and rinsed with distilled water to remove organic material (SWIFT 1967). Permanent slides were air dried and mounted in Naphrax ${ }^{\circledR}$ and prepared for LM.

Samples from sea turtles, Caulerpa taxifolia, Sinop Akliman Bay, Giffen collection and Martinique Island were examined by Olympus BX-51 and Nikon Eclipse_Ci microscopes $(\times 1000$ magnification $)$ at Dumlupınar University Biology Deparment in Turkey and Zeiss Axio Imager 2 (Carl Zeiss Microscopy Gmbh, Jena, Germany) at the Palaeoceanology Unit, Faculty of Geosciences, University of Szczecin in Poland. ImageJ was used for LM and SEM image measurements.

Ultrastructural analysis was performed with a Hitachi SU-8000 scanning electron microscope at Warsaw University of Technology, Faculty of Materials Science and Engineering, Hitachi S-4500 at Goethe University in Frankfurt am Main, and Hitachi S-4500 at University of Perpignan. Observations on nanostructure of Olifantiella mascarenica striae were performed by means of Hitachi NB5000 integrated system that consists of ultra-high performance FIB $(40 \mathrm{kV})$ and high resolution field emission (FESEM, $30 \mathrm{kV}$ ). This dual beam system enabled high-throughput specimen preparation, high-resolution imaging and analysis of frustule nanostructures. That construction enables SEM imaging during and after FIB cutting. The special low-damage cutting technique has been applied during diatom processing dedicated for materials sensitive to electron beam (e.g., VAsILE et al. 1999). The process of cutting was performed at accelerating voltage of $10 \mathrm{kV}$ for FIB. The siliceous valves of $O$. mascarenica and the transapical striae in particular have been cut at nanoscale and imaged prior to and during particular steps of cutting. The valve exterior and interior have been primarily cut along the transapical axis to image the canal-like structure located along the mantle, however, a few cuts along the valve surface apical axis have also been made.

Slides and processed material are deposited at the Department of Biology, Dumlupinar University, Kütahya (Turkey) and diatom collection (SZCZ) of the Palaeoceanology Unit, University of Szczecin, Szczecin (Poland).

\section{RESULTS}

Abundant populations of Olifantiella have been observed during examination of species composition in scrapes from the loggerhead sea turtle carapaces sampled at Turkish coast nesting grounds. Analysis of Olifantiella morphology growing on C. caretta revealed the presence of one characteristic taxon, described below as a new species. Some similarity to $O$. gorandiana and $O$. mascarenica was observed by SEM-based analysis of ultrastructure. This is the first report of epizoic populations of Olifantiella from loggerhead sea turtles. 
We also propose transfer of Navicula infirmitata GIFFEN as Olifantiella infirmitata (Giffen) Witkowsk1 et Snoeijs comb. nov., with morphological data based on LM and SEM observations.

\section{New Olifantiella taxa}

Olifantiella seblae Kaleli, Krzywda, Witkowski et Solak sp. nov. (Figs 2-19; LM 2-7, SEM 8-19)

Description: Valves elliptic to lanceolate with rounded to slightly protracted endings. $4.5-14.5 \mu \mathrm{m}$ long, 1.9-3.2 $\mu \mathrm{m}$ broad. Raphe straight, filiformis. Central raphe endings straight to slightly deflected toward the valve primary side in LM. Transapical striae in LM not resolvable.

Holotype: Slide SZCZ 19776, A.W. collection housed in the University of Szczecin, Poland., leg. Erhan KABUK

Isotype: NHM London, Slide BM 101921

Type locality: İztuzu Beach, Dalyan $\left(36^{\circ} 42^{\prime} 02^{\prime \prime} \mathrm{N}\right.$, 28॰41'31"E), Turkey.

Etymology: This species is dedicated to Sebla SolaK, wife of our friend Dr. Cüneyt SolaK.

Distribution: Thus far only observed in the type habitat, 177 specimens scrapped from 14 loggerhead sea turtles.

Type habitat: Carapace of nesting Loggerhead Sea turtles from İztuzu Beach, Turkey.

\section{Morphology \\ LM observations (Figs 2-7)}

Valves elliptic to lanceolate, with rounded to very slightly protracted ends (Fig. 2). Striae not detectable in LM, buciniportula may be visible as isolated point (Figs 2-7).

\section{SEM external view (Figs 8-11)}

Each transapical stria is composed of one macroareola, parallel at the valve center, becoming radiate and finally again parallel at apices, 40-46 in $10 \mu \mathrm{m}$ (Figs 8, 9, 11). Process opening oblong to sub-quadrangular (Fig. 10, arrow), close to valve margin (marinal structureless band). External proximal raphe endings expanded, straight to slightly deflected towards the valve primary side (Fig. 10). Striae on valve mantle composed of solitary oblong short macroareola (Fig. 11, arrow), at apices becoming smaller (Fig. 9). Terminal raphe endings terminate below the apices and are slightly deflected (Figs 9, 11), towards the valve primary side (Fig. 9). Girdle composed of several perforated bands, with two rows of apically elongate puncta (Fig. 11).

\section{SEM internal view (Figs 12-19)}

Valve interior flat with transapical striae, each composed of one macroareola. Raphe straight, filiformis. Internal central raphe endings simple, expanded, separated with double helictoglossa. Buciniportula composed of two flattened tubes with lateral opening, elevated (arrows) and located on mid-valve (Figs 14, 17, 19). Macroareola covered by hymenes, here corroded (Figs 14-19).

Taxonomic remarks: Olifantiella seblae observed in the epizoic samples and described as new to science revealed high morphologic plasticity. The smallest valves are elliptic- lanceolate with obtusely rounded apices, whereas the largest ones, narrowly lanceolate with somewhat protracted apices. In general this species shares characteristics with Olifantiella and pertains to the group that includes $O$. gorandiana. The two taxa are characterized by strongly narrow canal and complex buciniportula. In details the newly described taxon is similar to Olifantiella gorandiana in terms of overlapping valve size [length 5-8 $\mu \mathrm{m}$ in $O$. gorandiana (RIAUX-Gobin \& AL-Handal 2012, p. 201) versus 4.5-14.5 $\mu \mathrm{m}$ in $O$. seblae] with $O$. gorandiana valves rarely protracted. The two taxa differ in the shape of buciniportula, which in O. seblae is composed of 2 fan-like flattened tubes, while there are two supplementary small satellites in O. gorandiana. Also one other difference is the process opening position on the valve exterior. In $O$. seblae the process opening is located close to the structureless band along the valve margin, whereas in $O$. gorandiana the opening is always positioned within this band. Terminal raphe endings are slightly bent in the same direction and associated with strongly bent shallow grove in $O$. seblae whereas simple and slightly expanded in O. gorandiana. In RIAUX-GobIN (2015), transapical striae of O. gorandiana are parallel throughout becoming radiate at apices, whereas $O$. seblae has transapical striae radiate in the middle, becoming strongly radiate towards apices, with lower stria density (40-46 in $10 \mu \mathrm{m})$ compared to O. gorandiana $(60-63$ in $10 \mu \mathrm{m})$.

Olifantiella infirmitata (Giffen) Witkowski et Snoeijs comb. nov. (Figs 20-41; LM 20-34, SEM 35-41)

Basionym: Navicula infirmitata GIFFEN in GifFEN (1975). An account of the littoral diatoms from Langebaan, Saldanha Bay, Cape Province, South Africa. Botanica Marina 18: 71-95. p. 83, pl. 2, pp. 69-73 reproduced in Figs 6-10.

Type Material: slide 629, Giffen Collection NorthWest University, Research Unit for Environmental Sciences, South Africa (NIWR)

Type habitat: Langebaan Lagoon $\left(33^{\circ} 05^{\prime} \mathrm{S}, 18^{\circ} 02^{\prime} \mathrm{E}\right)$, Saldanha Bay, South Africa.

Description: Valves lanceolate with protracted, broadly rounded endings, 9.5-12.0 $\mu \mathrm{m}$ long, 1.9-3.1 $\mu \mathrm{m}$ wide. Raphe straight, external central endings barely observed in LM, approximate. Transapical striae barely resolvable with light microscope, here, only in Figs 13-16.

\section{Morphology}

SEM external view (Figs 35-37, 41)

Frustules rectangular in girdle view with rounded 


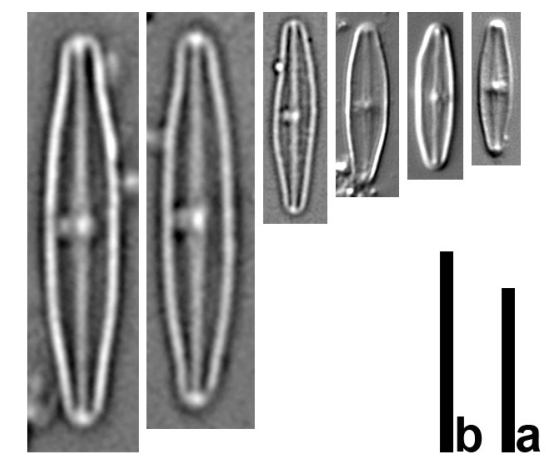

$2 \ldots 7$
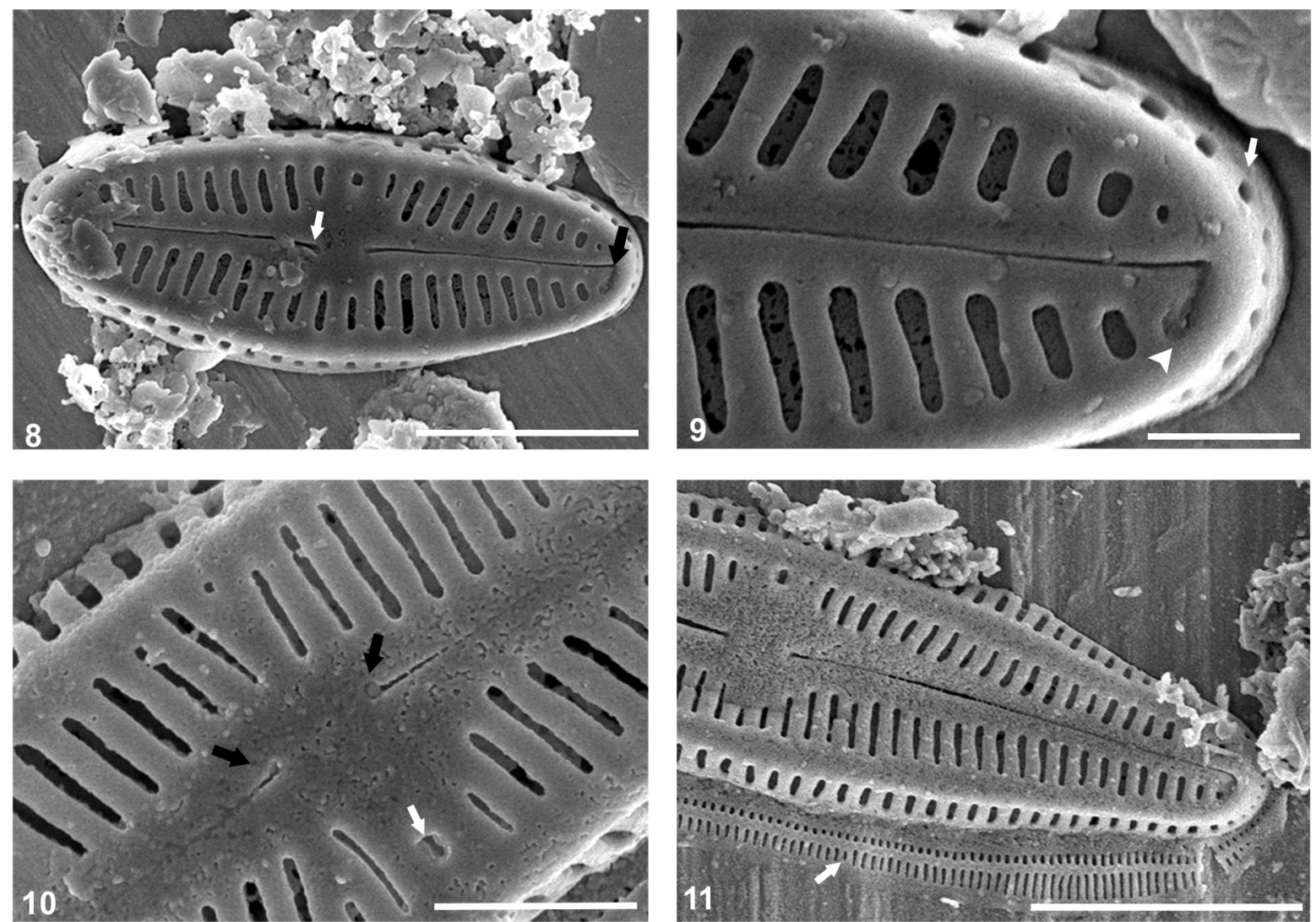

Figs 2-11. Olifantiella seblae Kaleli, Krzywda, Witkowski et Solak sp. nov.: (2-7) LM images of O. seblae., (5) Holotype image; (8-11) SEM external view of $O$. seblae., (8) Relatively small specimen showing proximal raphe endings bent towards the valve primary side (arrows) and terminal raphe endings (black arrow), (9) Detailed view of apical part of specimen illustrated in Fig. 8, note the distinct groove accompanying terminal raphe endings (arrowhead) and stria on mantle becomes smaller at apices (arrow), (10) Detailed view of central area, note the presence of process opening (arrow), external central raphe endings bent towards the valve primary side (black arrows), (11) Half of specimen showing distinct decrease in size of valve mantle areolae towards apex, note the cingular band with two rows of apically elongate punctae (arrow). Scale bars $10 \mu \mathrm{m}(\mathrm{a}, 4-7) ; 5 \mu \mathrm{m}$ (b, 2, 3); $2 \mu \mathrm{m}$ (8); $500 \mathrm{~nm}(9) ; 1 \mu \mathrm{m}(10) ; 3 \mu \mathrm{m}(11)$.

apices, girdle broad, composed of numerous bands. Girdle bands perforated with several rows of punctae. Valves elliptic-lanceolate in smallest to linear-lanceolate in longest specimens. Apices slightly set off to distinctly protracted, obtusely rounded. In SEM, striae composed of transapically positioned macroareola (BukHTIYARova 2006), parallel in the middle, becoming slightly radiate at apices, 36-40 in $10 \mu \mathrm{m}$. In SEM, transapical striae parallel in the middle becoming radiate at protracted apices (Fig. 35). In Fig. 36, process opening is observed (arrowhead). Striae forming macroareolae are depressed below valve face. The areola are covered with hymenes (Fig. 36, arrows). Valve face flat, with an opening of the buciniportula viewed within the central area (note the marginal remaining portion of the stria). In LM (Figs 31-34) and in the drawings of GIFFEN (1975) this structure is indicated as distinct punctum or stigma (Figs 20-24). The transapical striae depression below the valve face have a small opening (or fenestrulae, ca. $100 \mathrm{~nm}$ in diameter) penetrating towards the marginal canal. A large structureless area occurs in the transition from valve face 

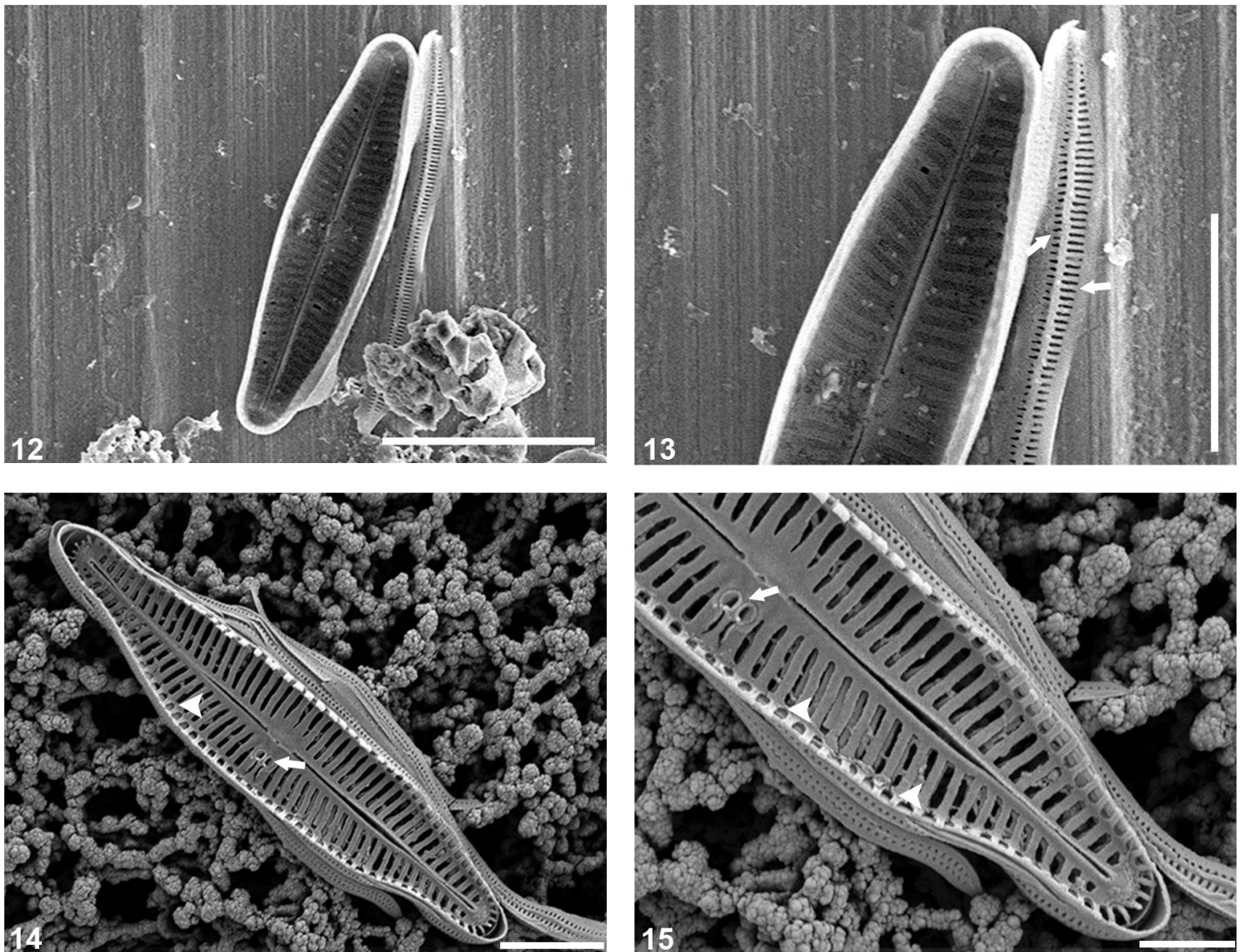

Figs 12-15. Olifantiella seblae Kaleli, Krzywda, Witkowski et Solak sp. nov.: (12-13) A series of images of same specimen illustrating valve internal structure. Fig. 12. Whole specimen internal view, (13) Close up of a specimen inllustrated in Fig. 12, detailed view of girdle band with two rows of narrowly elongated puncta, note the shorter puncta on advalvar part of cingular band (arrows); (14, 15) Corroded specimen showing the internal valve view areolae, buciniportula and narrow canal, (15) Close up of the specimen illustrated in Fig. 14, note the structure of the buciniportula (arrow) and the narrow canal through the valve (arrowheads). Scale bars $5 \mu \mathrm{m}$ (12); $3 \mu \mathrm{m}(13) ; 2 \mu \mathrm{m}(14) ; 1 \mu \mathrm{m}(15)$.

to mantle, being the roof of a canal-like structure (see internal view, Fig. 38, arrows).

The marginal canal opens externally by small and round fenestrulae (Fig. 40, arrowheads). The striation on the valve mantle ends by solitary round areolae or fenestrulae. Buciniportula is solitary (Figs 39, 40, arrowheads) with mantle areola at the apices becoming apically elongate (Fig. 37, arrowhead). Raphe straight, filiform with external central endings very slightly expanded and slightly deflected towards valve primary side (white arrow). Terminal raphe endings are simple, slightly expanded and terminate at the transition between valve face and mantle (Fig. 37). In SEM, the process opening is oblong (arrow in Fig. 36).

\section{SEM internal view (Figs 38-40)}

Valve interior flat with transapical striae composed of macroareola slightly elevated and virgae slightly depressed. Raphe straight and slit-like with internal proximal endings simple (Note a nodule in between these endings). Buciniportula solitary, trumpet-like, elevated above the valve surface. Internal side of valve mantle possess elevated, marginal canal structure continues along the valve mantle between both apices (Fig. 38).

Taxonomic remarks: Despite a small size and hyaline valve structure, GIFFEN (1975) observed the presence of a stigma or punctum but stated that this species is easily overlooked, with LM images often not informative enough to make consistent measurements. Ultrastructure of $N$. infirmitata indicates that this species belongs in Olifantiella. Specimens possess transapically elongate striae composed of single areola and tubular buciniportula. In terms of valve ultrustructure this taxon pertains to the group of taxa that includes Olifantiella mascarenica. The measurements of both taxa are similar (Table 1), with differences observed in the proximal raphe endings in external view.

The perforation of cingular bands, as well as fenestrulae, are also smaller in $O$. infirmitata. The striation is more or less similar being somewhat denser in $O$. mascarenica than in O. infirmitata (Table 1) and also quite parallel in $O$. mascarenica. The major difference between the two taxa is the marginal structureless area, which is narrow in $O$. mascarenica and broad in 

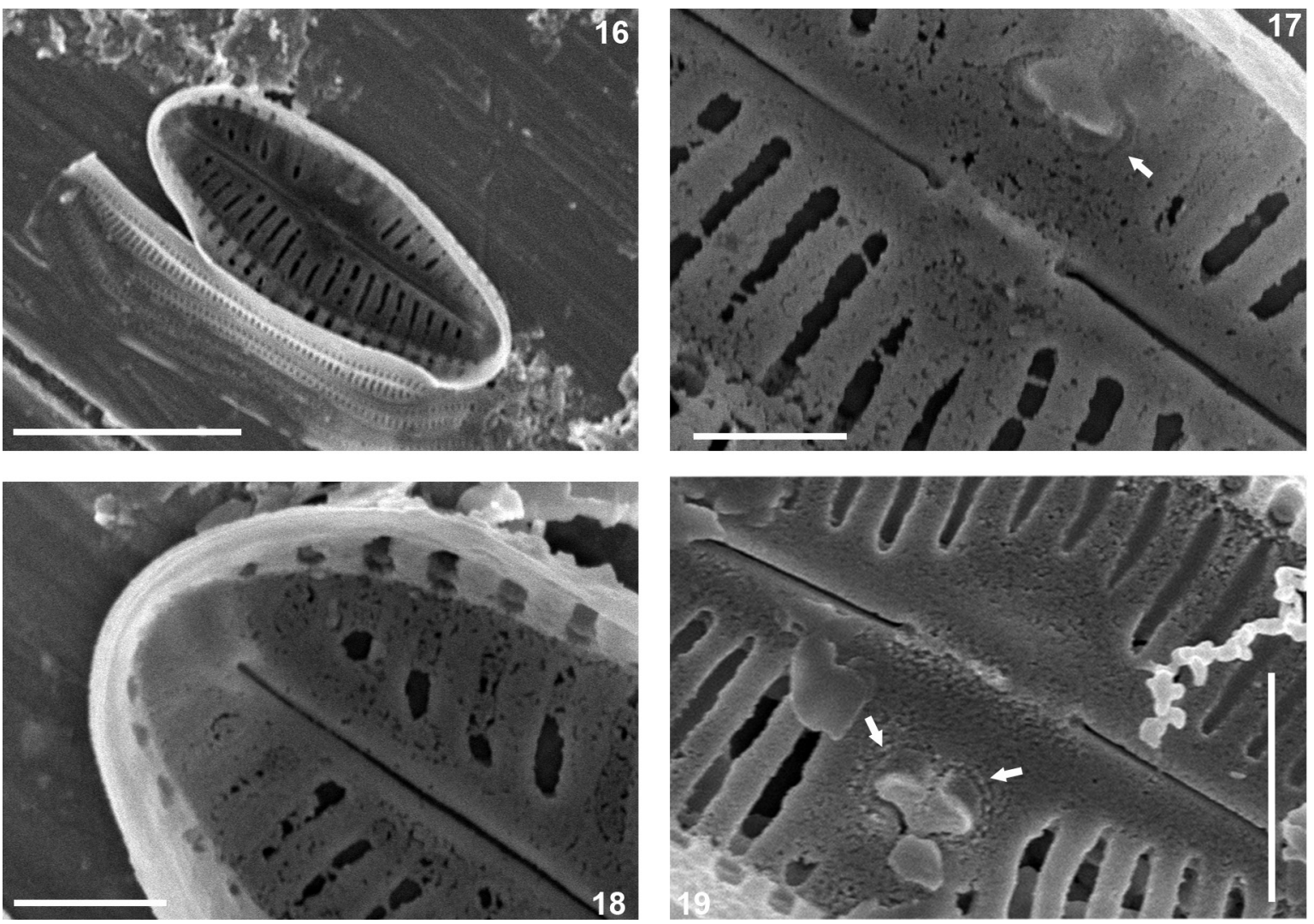

Figs 16-19. Olifantiella seblae Kaleli, Krzywda, Witkowski et Solak sp. nov.: (16) View of valve interior; $(17,19)$ Buciniportula composed of two flattened fan-like tubes (arrows); (18) Internal terminal raphe ending in the form of simple helictoglossa. Scale bars $3 \mu \mathrm{m}(16) ; 500 \mathrm{~nm}$ $(17,18) ; 1 \mu \mathrm{m}(19)$.

$O$. infirmitata. Fenestrulae in $O$. infirmitata are significantly smaller than in O. mascarenica. Likewise the mantle striae are elliptical in O. mascarenica whereas small and oblong in $O$. infirmitata.

\section{Established Olifantiella taxa}

Olifantiella cf. mascarenica Riaux-Gobin et Compère (Figs 42-57)

Specimens observed from Black Sea samples possess the characteristics of $O$. mascarenica described from Rodrigues Island by RIAUX-GoBIN \& AL-HANDAL (2012). Specimens collected from Sinop Bay, Black Sea coast have valves $6.0-10.3 \mu \mathrm{m}$ in length, 2.0-2.7 $\mu \mathrm{m}$ in width and 40 striae in $10 \mu \mathrm{m}$. The Black Sea specimens have somewhat more elongate ends with solitary tubular buciniportula. Adriatic Sea specimens have slightly elongated endings with buciniportula tubular and closer to central area in internal view, and were slightly longer, 7.8-11.1 $\mu \mathrm{m}$, width $2.3-2.5 \mu \mathrm{m}$ and with somewhat higher stria density $40-50$ in 10 $\mu \mathrm{m}$. Some valves resemble $O$. mascarenica illustrated in RiauX-Gobin \& AL-Handal(2012; Figs 4, 5) with distinctly elongated endings, 9.1-10.8 $\mu \mathrm{m}$ in length, $1.9-2 \mu \mathrm{m}$ in width and again with higher stria density, $45-55$ in $10 \mu \mathrm{m}$. The transapical striae are parallel throughout and become slightly convergent at apices in all populations. Due to the fact that the Black Sea and Adriatic Sea specimens possess somewhat more elongated valves and lower stria density we decided to keep this species tentatively as $O$. cf. mascarenica until further SEM studies results will be available.

\section{Olifantiella pseudobiremis Riaux-Gobin (Figs 58, 59)}

Only one valve of $O$. pseudobiremis was observed in sample from Sinop, Akliman Bay. The valve was 6.0 $\mu \mathrm{m}$ in length and $2.0 \mu \mathrm{m}$ in width with 40 striae in 10 $\mu \mathrm{m}$. This species was relatively rare in the type locality (Rodrigues Island, Indian Ocean, in RIAUX-GoBIN 2015), but has been later observed at Nosy Be Island (Madagascar) and in the South Pacific (Moorea Island, Society Archipelago, RIAUX-GoBIN pers. obs.).

Taxonomic Remark: Olifantiella pseudobiremis (one specimen observed during the present study) is described as rare and the probable tubular process (as previously observed through the valve in RiAuXGoBIN \& AL-HANDAL 2012, fig. 69) has not previously been detailed. The oblong external opening of the process is located in the central area of the frustule, near the proximal raphe endings, as in the $O$. mascarenica group. 

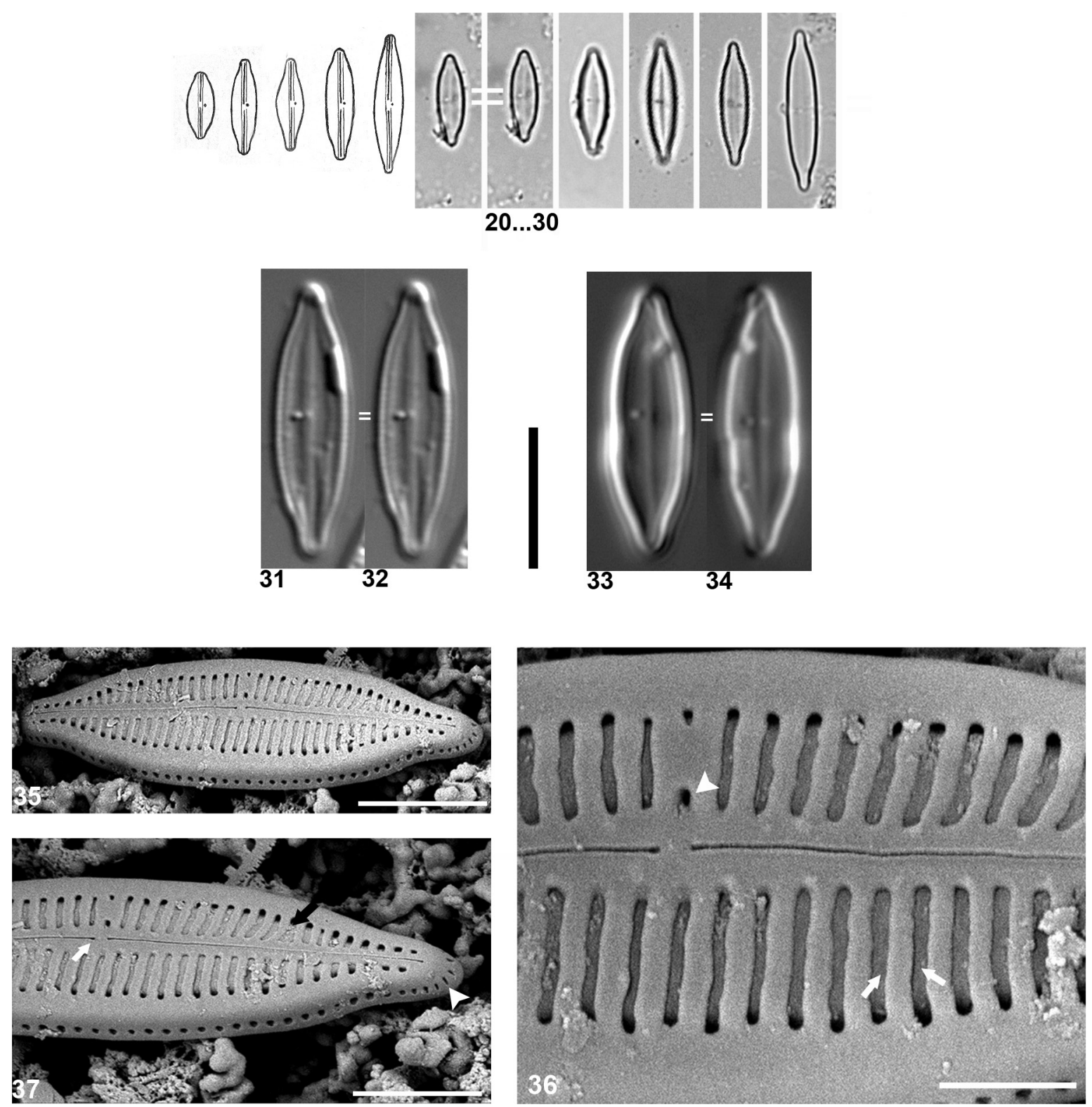

Figs 20-37. Olifantiella infirmitata (Giffen) Witkowski et Snoeijs comb. nov.: (20-24) Original drawings of Navicula infirmitata published by GifFen (1975, pl. 2, pp. 69-73); 25-34) LM images from the holotype slide in Giffen collection, sample 629; (35-37) External valve view, (35) External view of the whole specimen, (36) Close up of specimen illustrated in Fig. 35. Note the process opening (arrowhead) and hymenes covering the macroareolae (white arrows), (37) Close up of valve middle part of specimen illustrated in Fig. 35. Note the external proximal raphe endings slightly bent towards valve primary side (white arrow), and presence of Voigt discontinuity shown on valve secondary side (black arrow). Areola become apically elongate at the apices (arrowhead). Scale bars $10 \mu \mathrm{m}(20-30), 5 \mu \mathrm{m}(31-34), 3 \mu \mathrm{m}(35), 900 \mathrm{~nm}(36), 2 \mu \mathrm{m}(37)$.

\section{Cutting Olifantiella mascarenica valves via FIB technique (Figs 60-63)}

Specimens of $O$. mascarenica for nanocuts originated from Martinique Island (see above). Nanocuts were made on external and internal valve views and along apical axis in external position. Descriptions were clarified with traditional SEM (RIAUX-GobIN 2015), processing of valves revealed presence of a canal (similar to a bridge) along the valve mantle. The presence of septa delineating short chambers was not observed. The canal-like structure has no transverse subdivisions and entire over the valve periphery. The canal opens externally via fenestrulae ca. $100 \mathrm{~nm}$ in diameter (see definition in RiauX-Gobin 2015). The buciniportula opening on valve exterior is single for $O$. mascarenica, perpendicular to the valve internal surface. The external elliptical opening is close to the raphe and an inlet to buciniportula tube. Nanocuts through the valve face openings show that the second, elongate structure appears not connected to buciniportula tube inside the cell (Fig. 60, arrow). The larger opening appears to be modified striae and connected to the channel-like structure. The cingular bands have two rows of puncta (Fig. 60, black arrows).

Remarks: Attempts to nanocut frustules from the $O$. 

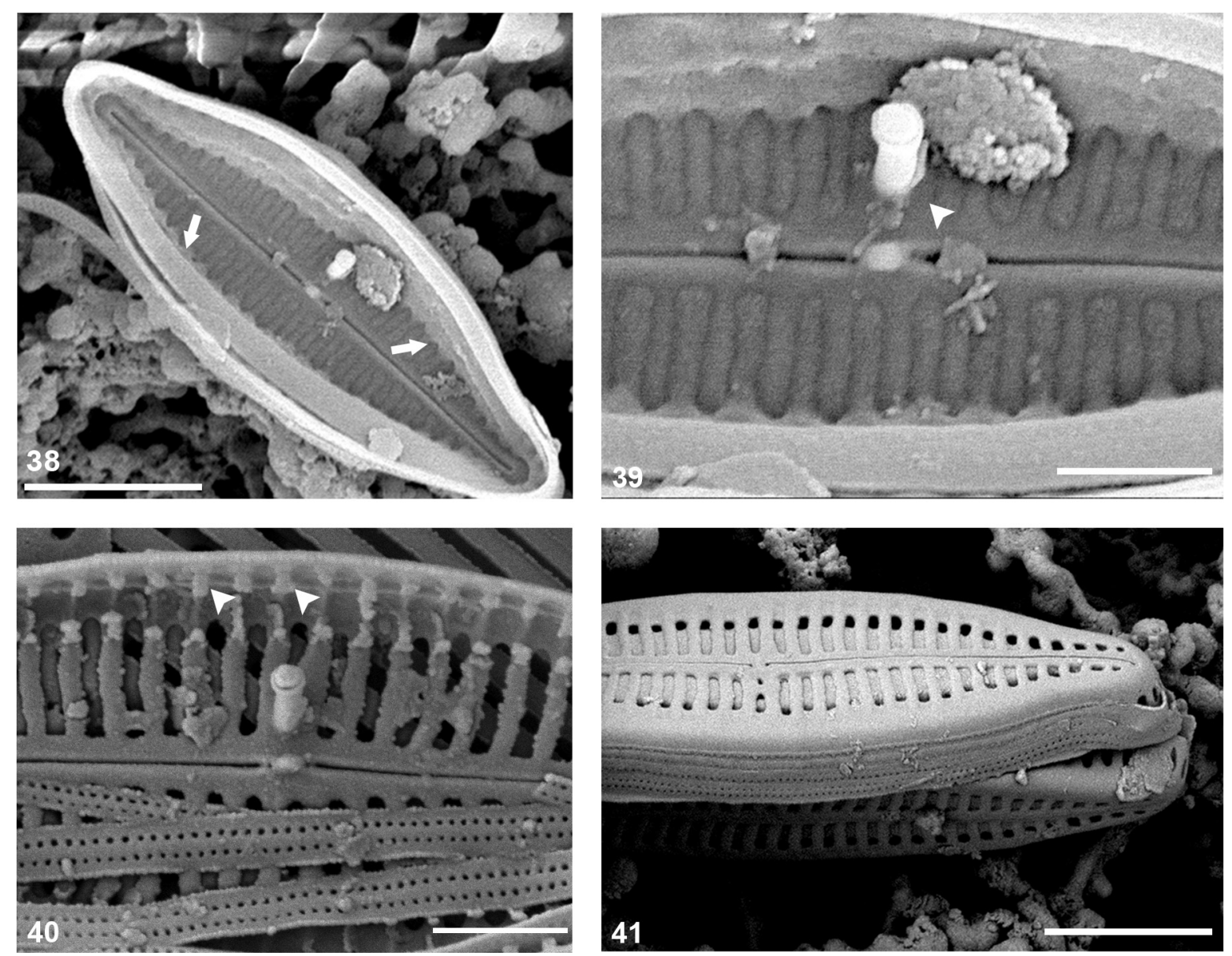

Figs 38-41. O. infirmitata (Giffen) Witkowski et Snoeijs comb. nov.: (38) Internal valve view with marginal canal (arrows); (39) Detail of specimen illustrated in Fig. 38, internal valve view with focus on buciniportula closed by a plug (arrowhead); (40) Internal valve view, note the corroded canal and hymenate areola occlusions. Well developed is the simple slit-like raphe with internal proximal raphe endings and small double helictoglossa. (41) Oblique view of the valve face and mantle with displaced, perforated girdle bands. Scale bars $2 \mu \mathrm{m}(38,41), 700$ $\mathrm{nm}(39), 900 \mathrm{~nm}(40)$.

gorandiana group failed. We did not observe the presence of extra space within the valve interior, while RiauX-Gobin \& AL-Handal (2012, Figs 30-31) clearly show small spaces that they interpreted as narrow fenestrulae. Possibly corroborating the latter observation, under SEM, a strongly narrow canal was observed in the internal side of a corroded specimen of O. seblae (see arrowheads in Figs 14-15).

\section{Discussion}

The genus Olifantiella was established relatively recently (RIAUX-GobIN \& COMPÈre 2009); Taxa belonging in this genus are small and have structures barely resolvable in LM and are thus difficult to identify. The use of electron microscopy is essential for reliable identification. The generic position of taxa belonging in Olifantiella is well determined by genus-specific processes - buciniportula and girdle bands (e.g., RIAUX-GobIN 2015). However, species identification requires a thorough ultrastructure analysis of valve external and internal surfaces including external proximal and terminal raphe endings, transapical striae and valve mantle.

Based on SEM observations, the following characters have been established as typical for Olifantiella: 1) presence of a more or less raised buciniportula, 2) each stria composed of one macroareola, 3) external proximal raphe endings bent towards the valve primary side, 4) hyaline band present along the valve-mantle boundary and internally the canal is more or less developed and present along the mantle interior, and 5) broad cingulum composed of numerous perforated bands (generally with two rows of puncta). In all established species, macroareolae are positioned below the valve surface and covered by finely perforated hymenes (RiauX-Gobin \& Compère 2009; RiauXGoBIN 2015). Despite these consistent characters, some variation in Olifantiella species is observed. Our observations confirm two groups of taxa belonging in Olifantiella. The first taxon treated in this survey $O$. infirmitata is closely related to the generitype $O$. mascarenica, and is here presented in the O. mascarenica 

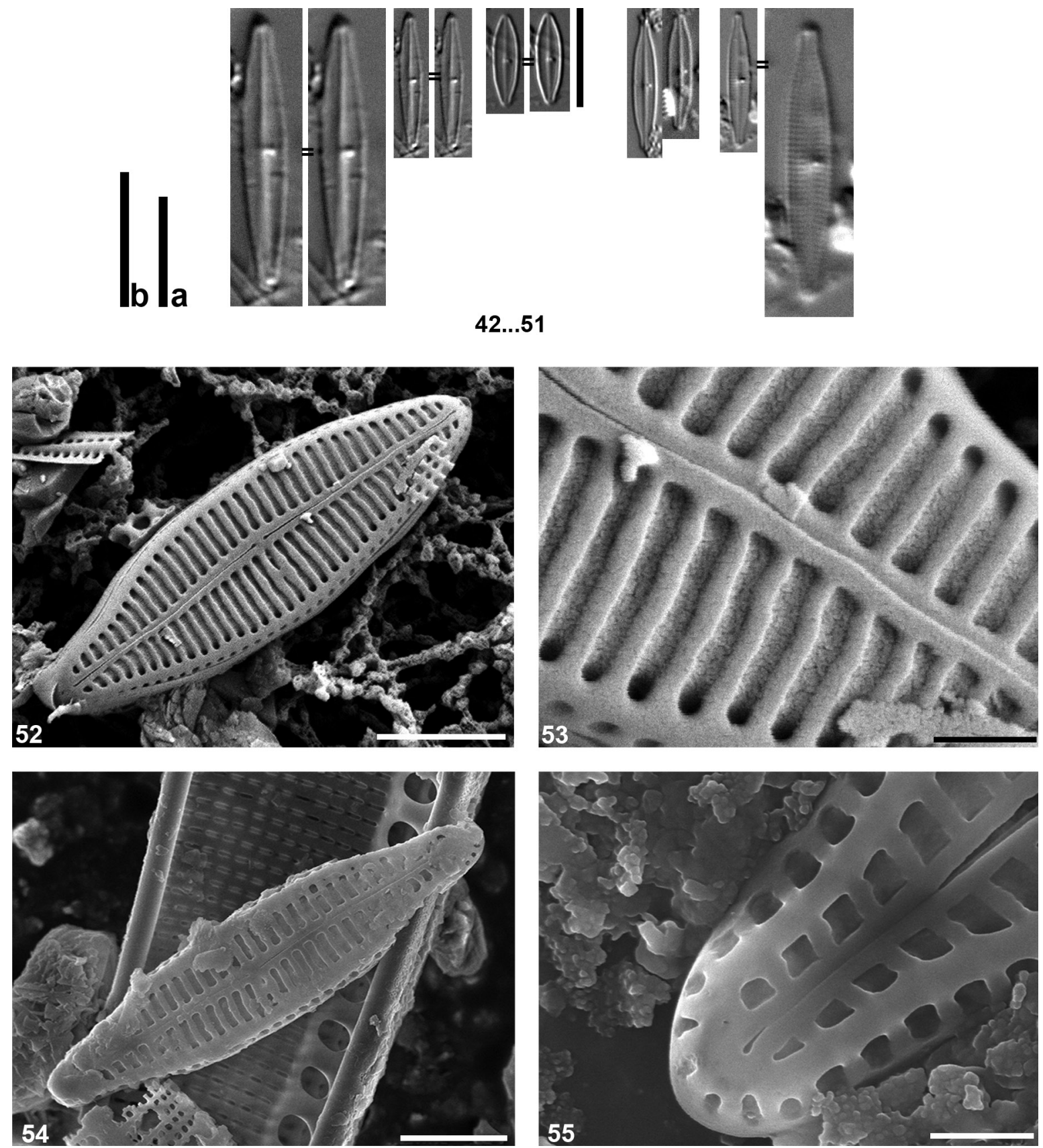

Figs 42-55. Olifantiella cf. mascarenica Riaux-Gobin et Compère: (48-51) Specimens from Sinop, Black Sea coast; (42-47, 52, 53) Specimens from Hvar Island, Adriatic Sea; $(54,55)$ Specimens from Sinop, Black Sea coast; (51) External valve view of $O$. cf. mascarenica; (52) Illustration of terminal raphe ending. Scale bars $10 \mu \mathrm{m}$ (a, 44-50), $5 \mu \mathrm{m}$ (b, 42, 43, 51); $2 \mu \mathrm{m}(52,54), 400 \mathrm{~nm}(53), 500 \mathrm{~nm}(55)$.

group. However, the two taxa differ in terms of marginal hyaline area at the valve face and mantle junction. The latter structure is narrow in $O$. mascarenica and broad in $O$. infirmitata. The fenestrulae are narrower in $O$. infirmitata. The mantle macroareolae are elliptical in O. mascarenica whereas small and oblong in $O$. infirmitata (Table 1).

In most taxa, including the generitype O. mascarenica, a canal spreading over the whole valve occurs at the mantle and valve face junction. This character, at first sight, is missing in other species belonging in the Olifantiella gorandiana group, but closer examination of $O$. gorandiana reveals a very narrow canal (RIAUXGobin \& AL-HANDAL 2012, see also SEM images of $O$. seblae, Figs 14 and 15). The separation of the two above groups of taxa are also principally supported by buciniportula structure and apical raphe endings. Variations in buciniportula structure include: 1) group conforming to $O$. mascarenica and $O$. rodriguensis with one or two tubular processes lying perpendicular/upright to the valve surface, and 2) group that includes $O$. gorandiana with complex buciniportula of tubular structures lying close to the valve. Terminal raphe endings in $O$. mascarenica group are simple and 

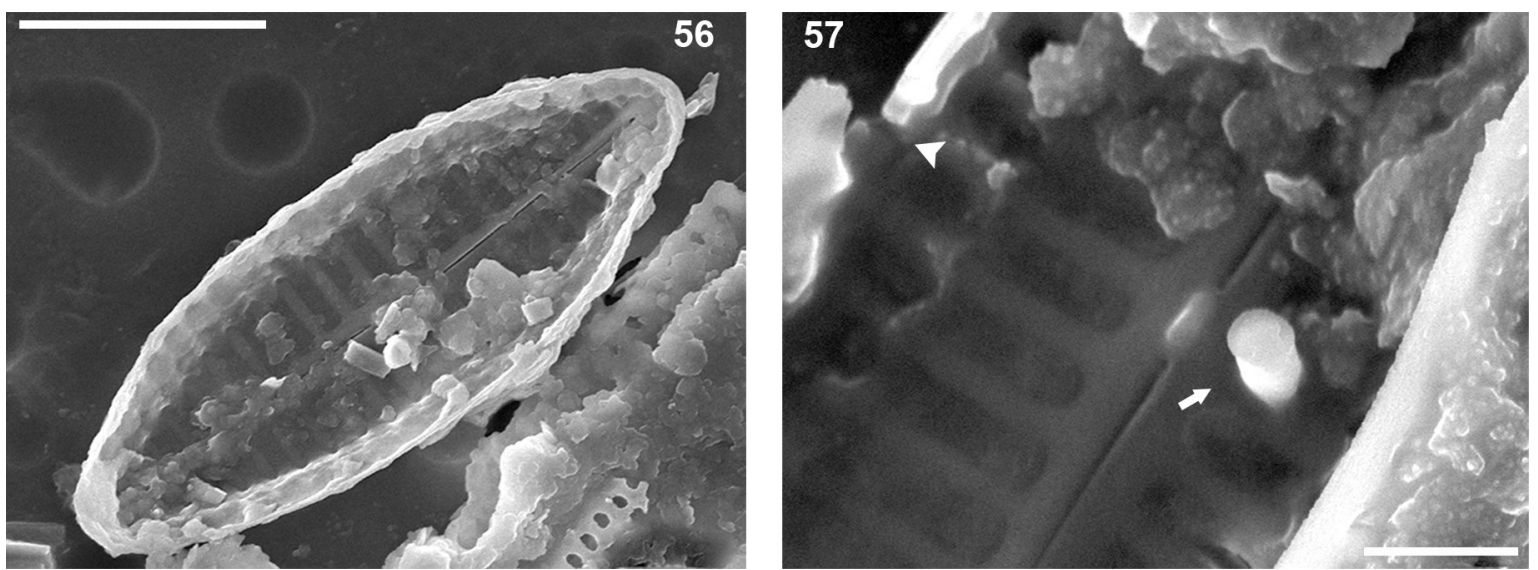

Figs 56-57. Olifantiella cf. mascarenica. Specimens from Sinop, Black Sea coast: (56) Internal valve view of O. cf. mascarenica; (57) Close up view of buciniportula. Scale bars $1 \mu \mathrm{m}(56) ; 500 \mathrm{~nm}(57)$.
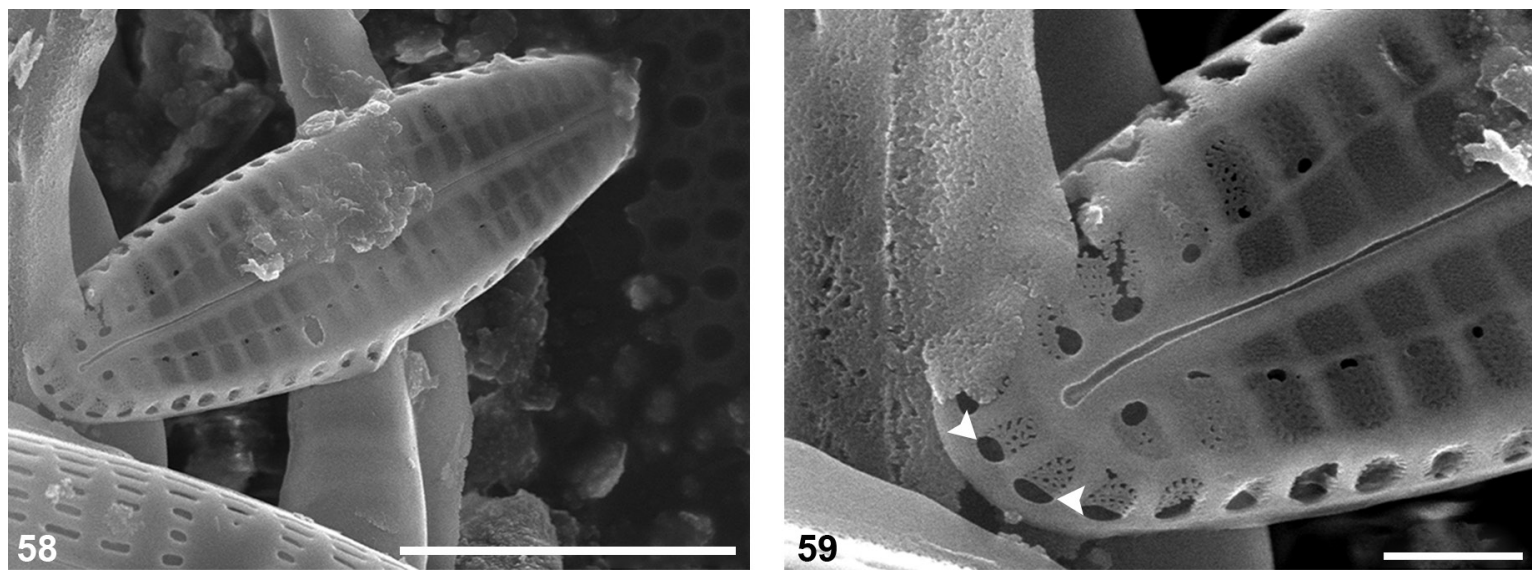

Figs 58-59. Olifantiella pseudobiremis Riaux-Gobin from Sinop, Black Sea coast: (59) Detailed view of specimen illustrated in Fig. 58, note the short striae composed of macroareolae covered by hymenes, and the large fenestrulae partially covered by complex and granulated hymenes showing small free apertures (arrowheads). Terminal raphe ending simple and slightly bent (Fig. 59). Scale bars $3 \mu \mathrm{m}$ (58); $500 \mathrm{~nm}(59)$.

terminate somewhat below apices. Members of the O. gorandiana group also have raphe endings simple, that terminate below apices, but are slightly bent. Note that $O$. seblae, a taxon included in the O. gorandiana group, is characterized by a shallow groove that continues over the apex surface, in continuation of the terminal raphe ending. Morphological features comparison of these two groups of species with similar taxa is provided in Table 1.

Olifantiella was previously reported predominantly from tropical Indo-Pacific coral reef habitats (RIAUX-GobIN \& COMPÈre 2009; LobBAN et al. 2012; RiauX-Gobin \& AL-Handal 2012; RiauXGobIN 2015). The genus was subsequently observed in the tropical West Caribbean, from coral habitat built on volcanic boulders and from bays with silt bottom and high turbitidy (DesRosiers 2014). At Martinique Island several established species including O. mascarenica, $O$. cf. paucistriata and $O$. gorandiana have been identified, next to several more taxa determined as Olifantiella sp. (DesRosiers 2014). More recently the occurrence of Olifantiella has been observed near
Antwerp (North Sea, VAN DE ViJVER et al. 2016) on the temperate Atlantic coast of Belgium. The present research shows Olifantiella to have a much broader geographic distribution that is a common component of temperate marine and brackish-water environments. Olifantiella species have been observed throughout the Mediterranean (Adriatic, Aegean) and abundant at places in the Black Sea. $O$. cf. mascarenica and $O$. pseudobiremis have been identified to a species level, however, analyses based on SEM are necessary to better estimate Olifantiella biodiversity of the genus in this geographic region.

Although habitats of the Mediterranean and Black Seas differ in terms of climatic conditions from the coral reef habitats, Olifantiella species established in sub-tropical to tropical Indo-Pacific, and Caribbean appear to tolerate fluctuations of marine water temperature and salinity. The Black Sea coast Akliman Bay, Sinop specimens of Olifantiella cf. mascarenica (Figs 42-55) have tubular buciniportula process and overall size dimensions that compare well to the RIAUXGobin \& Al-Handal (2012, Figs 4-10) illustrations 

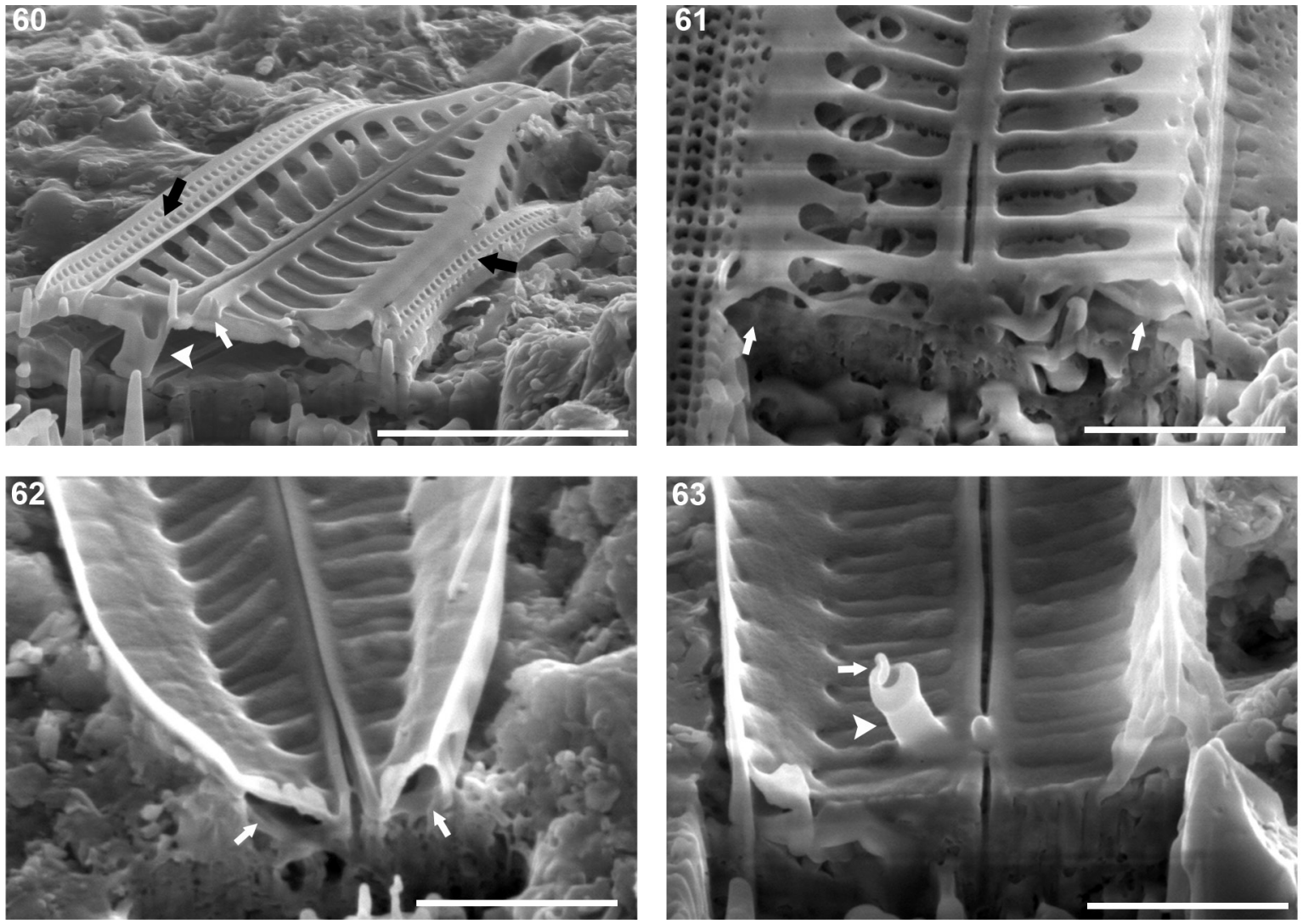

Figs 60-63. Nanocuts with FIB of Olifantiella mascarenica Riaux-Gobin et Compère from Martinique Island, Atlantic Ocean: (60) External valve view cut through central nodule (arrow) showing opening of the buciniportula (arrowhead), please note the cingular band with two rows of puncta (black arrow); (61) Marginal canal of cut valve external surface (arrows); (62) Cut of internal valve view showing canal (arrows) at the apex; (63) Cut of valve interior with hollow buciniportula close to the central nodule (arrowhead) and the canal. Note the small flap (plug) (arrow) partially closing the buciniportula (Fig. 63). Scale bars $2 \mu \mathrm{m}(60,61), 1 \mu \mathrm{m}(62,63)$.

from the original description of the species, except for more elongate shape and slightly lower stria density. Olifantiella pseudobiremis, described from Rodrigues Island as extremely rare by RIAUX-GOBIN \& $\mathrm{AL}_{-}$ HANDAL (2012), was observed as single specimen in multiple samples from Sinop, Akliman Bay, Black Sea coast (Figs 58,59) is a new record for Turkish diatom flora, but this taxon was also recently reported from Nosy Be Island (Madagascar) and Society Archipelago in the South Pacific (RIAUX-GoBIN unpublished observations). A large marginal canal is well identifiable for the latter taxon, with complex fenestrulae partly closed by ornamented complex velum. As well as in the original description, terminal raphe endings are slightly deflected towards valve primary side and each fenestrulae is covered by a granular velum and possess a small opening with two small spines. In addition, several species of Olifantiella have been observed in Crete and Greek Aegean Sea Islands (Anna Ulanova, pers. comm. May 2017).

The present observations and transfer of Navicula infirmitata GIFFEN expand the geographical repartition of Olifantiella infirmitata comb. nov. with type habitat in SW South Africa (Langebaan Lagoon, GIFFEN 1975). The taxon was also recorded by SNOEIJS \& KAUTSKY (1989) as Navicula infirmitata in the Baltic
Sea during the spring ice-break up. This species was also abundant in nuclear power station cooling waters located on the Swedish east coast (SNOEIJS \& NotTER 1993; SNOEIJS \& Balashova 1998).

The FIB technique brings more precise observations in nanoscale. Recently published results of molecular phylogeny of Olifantiella sp. from the Yellow Sea (HAN et al. 2018) show this genus to be in close relationship with Luticola D.G. MANN in Round et al. (1990) are together placed in Diadesmidiaceae D.G. Mann. Although in gross morphology Olifantiella and Luticola are different in respect to striation and girdle formation, the two genera appear to share some morphological characters: e.g., the presence of an internal channel-like structure and internal complex and hollow process in both genera. Due to the usually robust structure of the valves in Luticola the channel positoned on the valve face / mantle transition can be observed in standard SEM examination or even in LM (LeVKov et al. 2013). Recently BĄK et al. (2017) have illustrated the channel ultrastructure of L. galapagoenis Witkowski, Bąk, Kociolek, Lange-Bertalot et Seddon performed with the FIB. Indeed the two genera share this character positioned between the valve face and mantle. Nanocuts of Olifantiella mascarenica valves reveal the ultrastructure of the valve/mantle transition 
Table 1. Morphological characters of some species of genus Olifantiella. vps: Valve primary side.

\begin{tabular}{|c|c|c|c|c|c|c|}
\hline \multirow[t]{2}{*}{ Feature } & \multicolumn{3}{|c|}{ O. gorandiana group } & \multicolumn{3}{|c|}{ O. mascarenica group } \\
\hline & $\begin{array}{l}\text { O. gorandi- } \\
\text { ana Riaux- } \\
\text { Gobin }\end{array}$ & $\begin{array}{l}\text { O. seblae sp. } \\
\text { nov. }\end{array}$ & $\begin{array}{l}\text { O. mascar- } \\
\text { enica Ria- } \\
\text { ux-Gobin et } \\
\text { Compère }\end{array}$ & $\begin{array}{l}\text { O. cf. mascar- } \\
\text { enica }\end{array}$ & $\begin{array}{l}\text { O. infirmitata } \\
\text { comb. nov. }\end{array}$ & $\begin{array}{l}\text { O. pseudobire- } \\
\text { mis Riaux-Go- } \\
\text { bin }\end{array}$ \\
\hline Valve Shape & $\begin{array}{l}\text { elliptical, } \\
\text { slightly elon- } \\
\text { gated endings }\end{array}$ & $\begin{array}{l}\text { elliptic-lanceo- } \\
\text { late, rounded } \\
\text { to protracted } \\
\text { endings }\end{array}$ & $\begin{array}{l}\text { elliptical, } \\
\text { apiculate end- } \\
\text { ings }\end{array}$ & $\begin{array}{l}\text { elliptical, } \\
\text { slightly elon- } \\
\text { gated endings }\end{array}$ & $\begin{array}{l}\text { lanceolate, } \\
\text { protracted } \\
\text { broadly } \\
\text { rounded end- } \\
\text { ings }\end{array}$ & $\begin{array}{l}\text { naviculoid-elon- } \\
\text { gate }\end{array}$ \\
\hline Length $\mu \mathrm{m}$ & $6.8-8.1$ & $4.5-14.5$ & $8.4-10.7$ & $6.0-11.1$ & $9.5-12$ & $6-12$ \\
\hline Width $\mu \mathrm{m}$ & $1.8-2.3$ & $1.9-3.2$ & $2.1-2.7$ & $1.9-2.7$ & $1.9-3.1$ & $1.6-3$ \\
\hline Striae in $10 \mu \mathrm{m}$ & $60-63$ & $40-46$ & $42-49$ & $40-55$ & $36-40$ & $28-40$ \\
\hline Striae direction & $\begin{array}{l}\text { parallel } \\
\text { throughout, } \\
\text { becoming } \\
\text { slightly radi- } \\
\text { ate at apices }\end{array}$ & $\begin{array}{l}\text { parallel at the } \\
\text { center, becom- } \\
\text { ing slightly } \\
\text { radiate, parallel } \\
\text { at apices }\end{array}$ & sub-parallel & $\begin{array}{l}\text { parallel } \\
\text { throughout, } \\
\text { becoming } \\
\text { slightly con- } \\
\text { vergent at } \\
\text { apices }\end{array}$ & $\begin{array}{l}\text { parallel in } \\
\text { the middle, } \\
\text { slightly radi- } \\
\text { ate at apices }\end{array}$ & slightly radiate \\
\hline $\begin{array}{l}\text { Proximal raphe } \\
\text { endings }\end{array}$ & $\begin{array}{l}\text { inflated, } \\
\text { slightly de- } \\
\text { flected } \\
\text { away from } \\
\text { process open- } \\
\text { ing }\end{array}$ & $\begin{array}{l}\text { expanded, } \\
\text { straight to } \\
\text { slightly } \\
\text { deflected to- } \\
\text { wards vps }\end{array}$ & $\begin{array}{l}\text { inflated, very } \\
\text { slightly de- } \\
\text { flected } \\
\text { away from } \\
\text { process open- } \\
\text { ing side }\end{array}$ & $\begin{array}{l}\text { inflated, very } \\
\text { slightly de- } \\
\text { flected } \\
\text { away from } \\
\text { process open- } \\
\text { ing side }\end{array}$ & $\begin{array}{l}\text { very slightly } \\
\text { expanded, de- } \\
\text { flects towards } \\
\text { vps }\end{array}$ & $\begin{array}{l}\text { slightly inflated, } \\
\text { deflected away } \\
\text { from } \\
\text { the foramen }\end{array}$ \\
\hline $\begin{array}{l}\text { Terminal raphe } \\
\text { endings }\end{array}$ & $\begin{array}{l}\text { simple, } \\
\text { straight }\end{array}$ & $\begin{array}{l}\text { deflected to- } \\
\text { wards vps, ends } \\
\text { gently bent }\end{array}$ & $\begin{array}{l}\text { simple, } \\
\text { slightly de- } \\
\text { flected } \\
\text { on foramen } \\
\text { side }\end{array}$ & $\begin{array}{l}\text { simple, slightly } \\
\text { deflected } \\
\text { on foramen } \\
\text { side }\end{array}$ & $\begin{array}{l}\text { straight, } \\
\text { slightly ex- } \\
\text { panded }\end{array}$ & simple \\
\hline Buciniportula & $\begin{array}{l}\text { multiple, } \\
\text { flattened, (not } \\
\text { erected), with } \\
\text { two satellites }\end{array}$ & $\begin{array}{l}\text { double, flattened } \\
\text { tubular }\end{array}$ & $\begin{array}{l}\text { simple, } \\
\text { raised, } \\
\text { plugged }\end{array}$ & $\begin{array}{l}\text { simple, raised, } \\
\text { plugged }\end{array}$ & $\begin{array}{l}\text { double, cov- } \\
\text { ered with } \\
\text { a plug like } \\
\text { structure }\end{array}$ & not observed \\
\hline $\begin{array}{l}\text { External process, } \\
\text { opening, shape }\end{array}$ & $\begin{array}{l}\text { trapezoidal, } \\
\text { deeper split } \\
\text { into four sec- } \\
\text { tors, close to } \\
\text { margin }\end{array}$ & $\begin{array}{l}\text { oblong, near } \\
\text { margin }\end{array}$ & $\begin{array}{l}\text { oblong, } \\
\text { simple, close } \\
\text { to central area }\end{array}$ & $\begin{array}{l}\text { oblong, sim- } \\
\text { ple, close to } \\
\text { central area }\end{array}$ & $\begin{array}{l}\text { oblong, single } \\
\text { pore }\end{array}$ & $\begin{array}{l}\text { oblong, simple, } \\
\text { close to central } \\
\text { area }\end{array}$ \\
\hline Girdle bands & $\begin{array}{l}\text { several, two } \\
\text { rows of more } \\
\text { or less ob- } \\
\text { long poroids }\end{array}$ & $\begin{array}{l}\text { two rows of } \\
\text { puncta }\end{array}$ & $\begin{array}{l}\text { several, } \\
\text { opened, two } \\
\text { rows of el- } \\
\text { liptical small } \\
\text { poroids }\end{array}$ & $\begin{array}{l}\text { several, } \\
\text { opened, two } \\
\text { rows of el- } \\
\text { liptical small } \\
\text { poroids }\end{array}$ & $\begin{array}{l}\text { several rows } \\
\text { of small and } \\
\text { oblong puncta }\end{array}$ & $\begin{array}{l}\text { several, two rows } \\
\text { of puncta }\end{array}$ \\
\hline Marginal canal & $\begin{array}{l}\text { strongly nar- } \\
\text { row }\end{array}$ & strongly narrow & present & present & present & present \\
\hline
\end{tabular}


Dichotomous key to distinguish the taxa observed in this study, from Olifantiella mascarenica, O. gorandiana and Labellicula subantarctica

1 marginal canal-shaped structure very high to moderately high.............................................

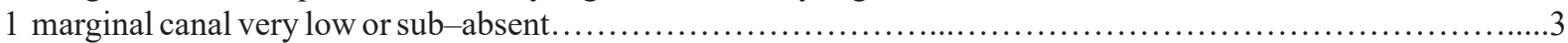

2 fenestrulae partially closed by an ornamented velum............................... Olifantiella pseudobiremis

2 open fenestrulae, more or less wide, raised tubular buciniportula .....................................

3 process as simple stigmata, sub-rostrate valve shape..............................abellicula subantarctica

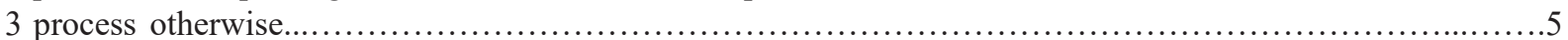

5 buciniportula composed of 2 flattened tubes and 2 satellites, terminal raphe endings simple ...................

Olifantiella gorandiana

5 buciniportula composed of 2 flattened hollow 'fan-like' structure, apical groove

Olifantiella seblae

4 fenestrulae relatively large.

Olifantiella mascarenica

4 fenestrulae narrow.

Olifantiella infirmitata

and allow to perform detailed observations on buciniportula and other valve characters of diatom species and genera.

\section{Conchusions}

Our observations indicate that Olifantiella taxa may be generally present on marine coasts with variable climatic conditions. Olifantiella diversity is best studied and highest in tropical marine coasts of Indo-Pacific coral reef habitats, but also reported in this first study from the Caribbean with somewhat less diversity in the Central and Eastern Mediterranean. Whereas water salinity is high in the Mediterranean, temperature is subject to annual oscillations from high in summer to much lower in winter. Olifantiella on Black Sea Turkish coasts appears to be abundant and includes warm water Indo-Pacific species and local elements, which require SEM examination. Seemingly, the oceanic Olifantiella species adapted to the Black Sea brackish-water conditions. Olifantiella seems to be a common component of the diatom assemblages of the temperate climate regions (SW Atlantic coasts of South Africa, the North Sea coast in Belgium, the Baltic Sea coast in Sweden). Finally, the abundant occurrence of epizoic Olifantiella on the marine turtles carapaces nesting in the Aegean east coast of Turkey is here described.

\footnotetext{
ACKNOWLEDGMENTS

This research has been funded by Polish Research Centre in Cracow by the research grant No. 2012/04/A/ST10/00544 (MK, AW), 2012/07/N/NZ8/02359 (AC), Polish Ministry of Science and Higher Education topical subsidy for the University of Szczecin, by Croatian Ministry of Science, Education and Sports (project 275-0000000-3186) and by Croatian science foundation (HRZZ, IP-2014-09-2945). The authors acknowledge Nickals DoERING Goethe University to operate the SEM. The authors thank anonymous reviewers for their helpful comments on the manuscript. Dimitri \& Yonko GoRAND (C2M, University of Perpignan, France), Genowefa DaniszewsKa-KowalczYK and Agnieszka KierzeK (Palaeoceanology Unit, University of Szczecin, Szczecin, Poland) are acknowledged for SEM assistance. We also acknowledge
}

the CNRS-USR 3278-Labex CORAIL (CR-G) and a Fulbright Fellowship (for KMc) for supporting this research. The authors would like to thank to Turkish Ministry of Environment and Urban Planning. Doğan SözBILEN and Ahmet Yavuz CANDAN are acknowledged for field sampling assistance. This work was supported by Council of Higher Education Foundation (Grant no: MEV-2016-04).

\section{REFERENCES}

BaşKale, E. \& Kaska, Y. (2005): Sea turtle nest conservation techniques on Southwestern beaches in Turkey. - Israel Journal Zoology 51: 13-26.

BąK, M.; Kociolek, J.P.; Lange-Bertalot, H.; Łopat, D.; Witkowski, A. et al. (2017): Novel diatom species (Bacillariophyta) from the freshwater discharge site of Laguna Diablas (Island Isabela $=$ Albemarle) from the Galapagos. - Phytotaxa 311: 201-224.

Bolten, A.B. (1999): Techniques for measuring sea turtles. - In: Eckert, K.L.; Bjorndal, K.A.; Abreu-Grobois, F.A. \& Donnelly, M. (eds): Research and management techniques for the conservation of sea turtles. - pp. 110-114, IUCN/SSC Marine Turtle Specialist Group, Washington, DC.

BukHtiYARova, L.N. (2006): Additional data on the diatom genus Karayevia and a proposal to reject the genus Kolbesia. - Nova Hedwigia Beiheft 130: 85-96.

Canbolat, A.F. (2004): A review of sea turtle nesting activity along the Mediterranean coast of Turkey. - Biol. Conserv. 116: 81-91

Desrosiers, C. (2014): Les diatomées benthiques des zones côtieres de Martinique : taxonomie, écologie et capacité bioindicatrice [PhD Thesis]. - 252 pp., Universite de Touluse.

Desrosiers, C.; Leflaive, J.; Eulin, A. \& Ten-Hage, L. (2014): Optimal colonization and growth of marine benthic diatoms on artificial substrata: Protocol for a routine use in bioindication. - Journal of Applied Phycology 26: 1759-1771.

GifFen, M.H. (1975): An account of the littoral diatoms from Langebaan, Saldanha Bay, Cape Province, South Africa. - Botanica Marina 18: 71-95.

HAN, J.; ZhaNG, L.; WANG, P.; YANG, G.; WANG, S.; LI, Y. \& PAN, K. (2018): Heterogeneity of intron presence/absence in Olifantiella sp. (Bacillariophyta) contributes 
to the understanding of intron loss. - Journal of Phycology 54: 105-113. DOI: 10.1111/jpy.12605

Levkov, Z.; Metzeltin, D. \& Pavlov, A. (2013): Luticola and Luticolopsis. - In: Lange-Bertalot, H. (ed): Diatoms of Europe. Diatoms of the European inland waters and comparable habitats, Volume 7. - 698 pp., Koeltz Scientific Books, Königstein.

Lobban, C.S.; Schefter, M.; Jordan, R.W.; Arai, Y.; Sasaki, A.; Theriot, E.C.; Ashworth, M.; RuCK, E.C. \& Pennesi, C. (2012): Coral-reef diatoms (Bacillariophyta) from Guam: new records and preliminary checklist, with emphasis on epiphytic species from farmer-fish territories. - Micronesica 43: 237-479.

Majewska, R.; De Stefano, M. \& Van De Vijver, B. (2017). Labellicula lecohuiana, a new epizoic diatom species living on green turtles in Costa Rica. Nova Hedwigia 146 (Special Issue): 23-31.

Margaritoulis, D.; Argano, R.; Baran, I.; Bentivegna, F.; Bradai, M.N.; Camiñas, J.A.; Casale, P.; De Metrio, G.; Demetropoulos, A.; Gerosa, G.; Godley, B.J.; Haddoud, D.A.; Houghton, J.; LAurent, L. \& LAZAR, B. (2003): Loggerhead turtles in the Mediterranean: present knowledge and conservation perspectives. - In: Bolten, A.B. \& Witherington, B.E. (eds): Loggerhead Sea Turtles. pp. 175-198, Smithsonian Books, Washington, DC.

Riaux-Gobin, C. (2015): The elusive genus Olifantiella (Bacillariophyta): South Pacific assemblage and Indo-Pacific biogeography. - Botanica Marina 58: 251-266

Riaux-Gobin, C. \& Al-Handal, A.Y. (2012): New species in the marine diatom genus Olifantiella (Bacillariophyta, Biraphidineae) from Rodrigues Island (Western Indian Ocean). - Fottea 12: 199-217.

Riaux-Gobin, C. \& Compère, P. (2009): Olifantiella mascarenica gen. \& sp. nov., a new genus of pennate diatom from Réunion Island, exhibiting a remarkable internal process. - Phycol. Res. 57: 178-185.

Round, F.E.; Crawford, R.M. \& Mann, D.G. (1990): The Diatoms. Biology \& Morphology of the Genera. 747 pp., Cambridge, Cambridge University Press.

Snoeis, P. \& Balashova, N. (1998): Intercalibration and distribution of diatom species in the Baltic Sea, Volume 5, The Baltic Marine Biologist Publication, 16e. - 144 pp., Opulus Press, Uppsala.

SNOEIJS, P.J.M. \& KAUTSKY, U. (1989): Effects of Ice-break on the Structure and Dynamics of a Benthic Diatom Community in the Northern Baltic Sea. - Botanica Marina 32: 547-562.

Snoeiss, P.J.M \& Notter, M. (1993): Benthic diatoms as monitoring organisms for radionuclides in a Brackish-Water coastal environment. - Journal of Environmental Radioactivity 18: 23-52.

SwiFT, E. (1967): Cleaning diatom frustules with ultraviolet radiation and peroxide. - Phycologia 6: 161-163.

Van De Vijver, B.; Frenot, Y.; Beyens, L. \& LangeBertalot, H. (2005): Labellicula, a new diatom genus (Bacillariophyta) from île de la Possession (Crozet Archipelago, Subantarctica). - Cryptogamie Algol. 26: 125-133.

Van De Vijver, B.; Mertens, A. \& Van Dam, H. (2016): Olifantiella elisabethiana, a new raphid diatom species (Bacillariophyta) observed in the Port of Antwerp (Belgium). - Phytotaxa 261: 251-259.

Vasile, M.J.; Nassar, R.; XIE, J. \& Guo, H. (1999): Microfabrication techniques using focused ion beams and emergent applications. - Micron 30: 234-244.

Žuljević, A. \& Antolić, B. (2000): Synchronous release of male gametes of Caulerpa taxifolia (Caulerpales, Chlorophyta) in the Mediterranean Sea. - Phycologia 39: $157-159$.

(C) Czech Phycological Society (2018)

Received December 18, 2017

Accepted May 16, 2018 